\title{
Androgynomonoecious Jatropha curcas: Chromosomes, Isozymes, and Flowers Gender
}

\author{
Triadiati Triadiati ${ }^{{ }^{*},}$ Kurniati $^{2}$, Utut Widyastuti ${ }^{1 \dagger}{ }^{1}$ Dasumiati $^{3}$ \\ ${ }^{1}$ Department of Biology, Faculty of Mathematics and Natural Sciences, IPB University (Bogor Agricultural University), Dramaga \\ Campus, Bogor, Indonesia \\ ${ }^{2}$ Graduate Program in Plant Biology, Graduate School, IPB University (Bogor Agricultural University), Dramaga Campus, Bogor, \\ Indonesia \\ ${ }^{3}$ Department of Biology, Faculty of Sciences and Technology, Syarif Hidayatullah State Islamic University of Jakarta, South Tangerang, \\ Indonesia
}

\section{ARTICLE INFO}

Article history:

Received September 28, 2018

Received in revised form May 21, 2019

Accepted June 30, 2019

\section{KEYWORDS:}

flowers inflorescence,

Jatropha curcas,

andromonoecious

\begin{abstract}
Jatropha curcas (J. curcas) is usually monoecious plants, which have male and female flowers on the same inflorescence. However, $J$. curcas can be found as an androgynomonoecious plant (have male, female, and hermaphrodite flowers), even though very rare. Androgynomonoecious $J$. curcas can be identified after six months of planting when it had started flowering. Therefore, it is important to identify the characteristics of androgynomonoecious $J$. curcas that can differentiate between androgynomonoecious and monoecious plants in earlier stages of growth. The objectives of the research were to observe isozymes, chromosome and flowers gender of androgynomonoecious and monoecious $J$. curcas Banten and Lampung accessions. Seeds from five genotypes of $J$. curcas were used in the research. The observation was carried out on the chromosome and isozymes (Peroxidase and Esterase isozymes) could be used as markers to differentiate androgynomonoecious and monoecious plants. Observations about the flower gender from offsprings derived from different seeds were important to know the inheritance of flower gender. The androgynomonoecious and monoecious $J$. curcas were diploid with number of chromosomes $2 n=2 x=22$. The chromosomes of androgynomonoecious have longer than that of monoecious $J$. curcas. The isozymes of androgynomonoecious $J$. curcas had four alleles and monoecious $J$. curcas (Banten female monoecious) had three alleles. The flower inflorescence and gender derived from androgynomonoecious plants were unstable, due to androgynomonoecious is intermediate state.
\end{abstract}

\section{Introduction}

Jatropha curcas (J. curcas) is an original plant from tropical America belonging to the family of Euphorbiaceae. Commonly, J. curcas has male and female flowers on the same inflorescence in the plant (Hartati et al. 2009), there is currently some J. curcas with hermaphrodite flowers, but very rarely found. $J$. curcas with hermaphrodite flowers are classified as andromonoecious type (have hermaphrodite and male flowers in the same plant) and androgynomonoecious type (have male, female, and hermaphrodite flowers in same the plant) (Dellaporta and Urrea 1993; Makkar et al.

\footnotetext{
* Corresponding Author

E-mail Address: adiatiipb@gmail.com
}

2008; Andriano-Anaya et al. 2016). Hermaphrodite flowers tended to perform self-pollination (Hartati 2009; Dasumiati et al. 2015). Self-pollinated plants will produce homogeneous offsprings than crosspollinated plants (monoecious) which generally produce heterogeneous offsprings (Raju and Ezradanam 2002). Therefore, it is very important to study early detection for sex type of $J$. curcas that produces hermaphrodite flowers as an indicator for $J$. curcas breeding.

The sex type of $J$. curcas cannot be identified when the plant still seedling due to it does not have flowers. Sex types of J. curcas can be identified after six months of planting or when it has started flowering. Therefore, the androgynomonoecious $J$. curcas characters need to be observed as a selection criterion in the seedling phase. 
The early detection of sex types in J. curcas can be identified through the chromosome analysis, isozymes, and continued by the analysis of reproductive character (flower gender). Chromosome analysis is used to explain the inheritance of genetic materials and the relationship between species through the number and size of chromosomes (Plummer et al. 2003). Chromosome analysis also has been used to analyze the diversity of plants, such as those performed by Escudero et al. (2010), which evaluates the variation of chromosome number in Cyperaceae. Talukdar (2010) used a chromosome analysis to characterize and compare the three varieties of crops grass pea. To measure the diversity of plant species, also have been carried through isozymes techniques. Isozyme is an enzyme that is a direct product of a gene that has an active molecule and different chemical structures but catalyzes the same chemical reaction. Enzymes are protein biocatalisator for physiological processes that its role controlled genetically (Asante and Laing 2001). Some isozyme known to associated with or related to agronomic characters (Stalker and Mozingo 2001). The isozyme analysis can be used as genetic markers for studying variations of individual in a population (Yunus 2007). Some enzymes were used to differentiate the flower gender i.e, Peroxidase (PER) and Esterase (EST) enzymes (Sharma et al. 2010), as in the Hippophae rhamnoides L. (Shirkot et al. 2009).

Studies on early detection of sex types of plant on J. curcas is still limited. The purpose of this research was to identify markers of androgynomonoecious on $J$. curcas by comparison to monoecious J. curcas through chromosomes and isozymes characters. Characters of $J$. curcas that can be used to differentiate between androgynomonoecious and monoecious $J$. curcas were chromosomes and isozymes. Furthermore, this study observed the flowers gender inherited from the seeds of androgynomonoecious flowers. The results of this study are expected to characterize the characters of $J$. curcas as selection criteria in J. curcas breeding.

\section{Materials and Methods}

\subsection{Plant Materials}

The seeds from five genotypes of J.curcas, i.e.: seeds from female flowers of androgynomonoecious Lampung accession (LFT), seeds from hermaphrodite flowers of androgynomonoecious Lampung accession(LHT), seeds from female flowers of androgynomonoecious Banten accession (BFT), seed from hermaphrodite flowers of androgynomonoecious Banten accesion (BHT), and seeds from female flowers from monoecious of Banten accession (BFM). Each genotype was represented by 15 seeds for germinated and planted. This study used collection of $J$. curcas genotypes belonging to the first author.

\subsection{Chromosomes Analysis}

Five germinated seeds from every five genotypes of J. curcas (BFT, BHT, LFT, LHT, and BFM) were using for this analysis. The seedling roots from each genotype were used for measurement of chromosomes number and length. Fresh root tips (5-10 mm length) were incubated in $0.2 \%(\mathrm{w} / \mathrm{v})$ colchicine for 3 hours at $7^{\circ} \mathrm{C}$. The root tips were fixed in a $45 \%(\mathrm{w} / \mathrm{v})$ acetic acid solution for 10 minutes at room temperature. The root tips were hydrolysed in $1 \mathrm{~N} \mathrm{HCl}: 45 \%$ acetic acid $(3: 1, v / v)$ solution for 3 minutes in a $60^{\circ} \mathrm{C}$ water bath. The pieces of root tips were stained with $1 \%(\mathrm{w} / \mathrm{v})$ aceto orcein for 24 hours. Furthermore, root pieces were made into preparation by placed on a glass slide, it was closed with a cover glass and pressed. Preparation was observed under a microscope to count the number of chromosomes and measure the length of chromosomes. The chromosomes' length was measured using the application Image $1.42 \mathrm{q}$ (http://rsbweb.nih.gov/ij/).

\subsection{Isozymes Analysis}

Five seeds of each five genotypes of J. curcas (BFT, BHT, LFT, LHT, and BFM) were planted in a polybag. Isozymes analysis using young leaf (second leaf of shoot tip) from two months old-plant. Two grams of a leaf was extracted using $0.5 \mathrm{ml}$ buffer solutions (extraction buffer) and transferred to the starch gel. Extraction buffer consist of $10 \mathrm{mM} \mathrm{L}$-ascorbic acid, 40 mM L-cystein, 20\% Triton X-100, 0.25 g PVP-40 (polyvinyl polypyrrolidone), and $0.1 \mathrm{M} \mathrm{Na}_{2} \mathrm{HPO}_{2} \cdot \mathrm{H}_{2} \mathrm{O}$ pH 7.0 (phosphate buffer). The isozymes were separated using starch gel that was made from $13 \%$ $(\mathrm{w} / \mathrm{v})$ potato starch in $20 \mathrm{ml}$ gel buffer ( $5 \mathrm{mM}$ L-histidin monohydrate $\mathrm{pH}$ 6.0). Electrophoresis analysis was performed using electrophoresis buffer $(50 \mathrm{mM}$ citric acid monohydrate, $150 \mathrm{mM}$ tris hydroxymethyl aminomethane, $\mathrm{pH}$ 6.0) during four hours with a constant voltage of $200 \mathrm{~V}$ (Soltis and Soltis 1989). Peroxidase (PER) and Esterase (EST) were observed by soaking the gel in substrate solution for PER (50 
$\mathrm{mM}$ buffer sodium acetate $\mathrm{pH} 5.050 \mathrm{ml}, \mathrm{CaCl}_{2} 50$ $\mathrm{mg}, \mathrm{H}_{2} \mathrm{O}_{2} 3 \% 0.25 \mathrm{ml}$, 3-amino-9 ethylcarbazole 25 $\mathrm{mg}, \mathrm{N}, \mathrm{N}$-dimethylformamide $2 \mathrm{ml}$ ) and EST (100 mM buffer Na-phosphate pH $6.050 \mathrm{ml}, \alpha$-naphthylacetic acid $25 \mathrm{mg}, \beta$-naphthylacetic acid $25 \mathrm{mg}$, acetone 5 $\mathrm{ml}$, fast blue RR Salt $1 \mathrm{ml}$ ) for $60-120$ minutes. The position of isozyme bands was measured as relative electrophoretic mobility between band positions to relative electrophoresis mobility (Rf). Only clear isozyme bands were scored and enzymatic scheme diagrams painted according to Rf values.

\subsection{Observations of Flower Gender and Plant Sex Types}

Each of five genotypes of $J$. curcas (BFT, BHT, LFT, LHT, and BFM) were planted randomly on the field with a planting distance of $2 \times 2 \mathrm{~m}$. We observed flower gender and plant sex type from the seedling which had been observed chromosome and isozymes. To analyzed flower gender and plant sex type stabilization, we observed during the first flowering season.

\subsection{Data Analysis}

Data were analyzed using SPSS version 22 . The data analysis of chromosomes and isozyme displayed in the description. The length of chromosomes was conducted using analysis of variance (ANOVA) followed by the Duncan Multiple Range Test (DMRT) at 5\% level.

\section{Results}

\subsection{Chromosomes Analysis}

The characters that observed in chromosome analysis of $J$. curcas were chromosomes number and length. The five genotypes of $J$. curcas have 22 chromosomes (diploid: $2 \mathrm{n}=2 \mathrm{x}=22$ ) (Figure 1 ). The range of chromosomes length of five genotypes of $J$. curcas was 1.19 to $2.69 \mu \mathrm{m}$. The average chromosomes length were different $(\mathrm{p}<0.05)$ among the five genotypes were observed. The chromosomes' length of BHT and LHT larger than that of LFT, BFT, and BFM, on the other side, the chromosomes length of BFT and BFM were similar (Table 1).

\subsection{Isozymes Analysis}

Isozymes analysis was performed using the PER and EST enzymes. Isozymes of EST and PER have a difference in the number of bands on electrophoregram. Band pattern based on Rf value

Table 1. Chromosome length of androgynomonoecious and monoecious J. curcas

\begin{tabular}{cccccc}
\hline \multirow{2}{*}{$\begin{array}{c}\text { Chromosome } \\
\text { pairs }\end{array}$} & \multicolumn{5}{c}{ Chromosome length $(\mu \mathrm{m})$} \\
\cline { 2 - 5 } & $\begin{array}{c}\text { Androgynomonoecious } \\
\text { plants* }\end{array}$ & $\begin{array}{c}\text { Monoecious } \\
\text { plants }^{*}\end{array}$ \\
\cline { 2 - 5 } & BFT & BHT & LHT & LFT & BFM \\
2 & 1.96 & 2.57 & 2.42 & 2.69 & 1.93 \\
3 & 1.87 & 2.78 & 2.71 & 2.45 & 1.84 \\
4 & 1.71 & 2.64 & 2.47 & 2.00 & 1.67 \\
5 & 1.62 & 2.16 & 2.42 & 2.19 & 1.40 \\
6 & 1.61 & 2.53 & 2.40 & 2.15 & 1.56 \\
7 & 1.55 & 2.31 & 2.34 & 2.04 & 1.50 \\
8 & 1.47 & 2.28 & 2.23 & 1.96 & 1.43 \\
9 & 1.42 & 2.09 & 2.22 & 1.88 & 1.41 \\
10 & 1.36 & 1.88 & 2.16 & 1.76 & 1.26 \\
11 & 1.26 & 1.66 & 1.99 & 1.66 & 1.22 \\
\hline Average** & 1.19 & 1.54 & 1.67 & 1.68 & \\
\hline
\end{tabular}

${ }^{*}$ BFT: seedling from female flower of androgynomonidereious Banten accession, BHT: seedling from hermaphrodite flower of androgynomonoecious Banten accession, LHT: seedling from hermaphrodite flower of androgynomonoecious Lampung accession, LFT: seedling from female lower of androgynomonoecious Lampung accession, BFM: seedling from female flower of monoecious Banten accession **Number followed by the same letter in the same row indicate was not significantly different (Duncan test, $\mathrm{p}<0.05$ )
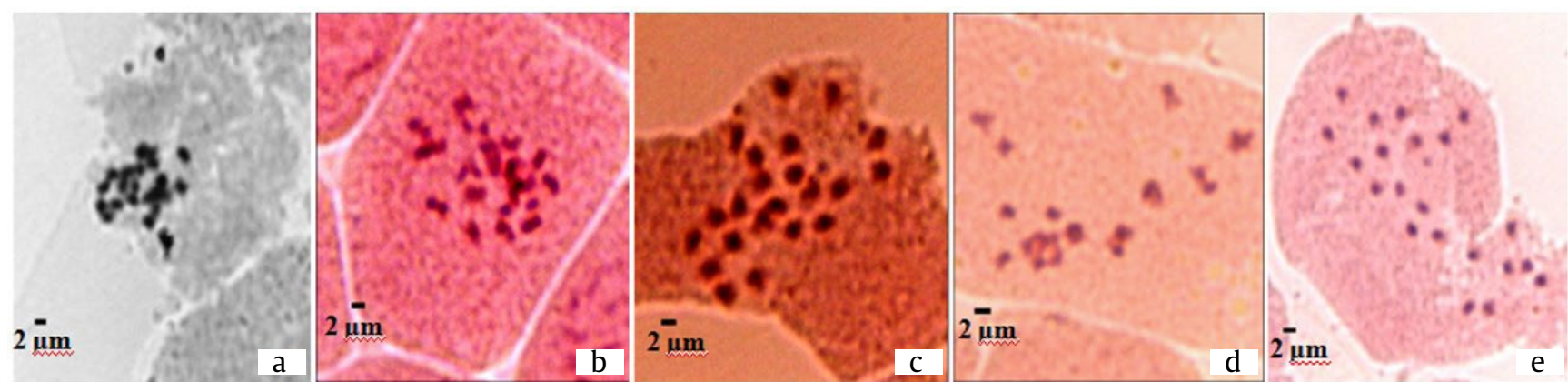

Figure 1. Chromosomes of androgynomonoecious and monoecious J. cucras. (a) BFT: seedling from female flower of androgynomonoecious Banten accession, (b) BHT: seedling from hermaphrodite flower of androgynomonoecious Banten accession, (c) LHT: seedling from hermaphrodite flower of androgynomonoecious Lampung accession, (d) LFT: seedling from female flower of androgynomonoecious Lampung accession, (e) BFM: seedling from female flower of monoecious Banten accession 
of these isozymes was varied. Esterase isozyme has two band patterns (Figure 2a and c). In the first band pattern consists of four bands (at Rf 0.20, 0.37, 0.50 , and 0.77 ) was formed by LFT, LHT, BHT, and BFT genotype. The second pattern consists of three bands (at Rf $0.37,0.50$, and 0.77 ) was formed by BFM genotypes. On the other side, Peroxidase isozyme has two band patterns (Figure $2 \mathrm{~b}$ and $\mathrm{d}$ ). In the first band pattern consists of four bands (at Rf $0.10,0.80$, 0.83 , and 0.96) was formed by LFT, LHT, BHT, and BFT genotypes. The second pattern consists of three bands (at Rf 0.10, 0.80, and 0.96) was formed by BFM genotype.

\subsection{The Flower Gender and Plant Sex Type in J. curcas}

Seeds derived from female flowers (BFT and LFT) and hermaphrodite flowers from androgynomonoecious (BHT and LHT) J. curcas produced offsprings of androgynomonoecious plants sex type. On the other side, seeds derived from the female flowers (BFM) of monoecious J. curcas produced offsprings of monoecious plants sex type (Table 2).

Plant sex type of androgynomonoecious (from BFT, BHT, LHT, and LFT seeds) produced four flower gender inflorescence, whereas monoecious plants (from BFM seeds) produced monoeciuos flower inflorescence. The androgynomonoecious plants have different percentages of flower gender on the plant. Among androgynomonoecious plants, BFT and LHT genotypes have four flower inflorescence types, that is androgynomonoecious (female, male, and hermaphrodite flowers), andromonoecious (male and hermaphrodite flowers), monoecious (female and male flowers), and male flower inflorescences. On the contrary, androgynomonoecious plants, BHT genotype only has three inflorescence types
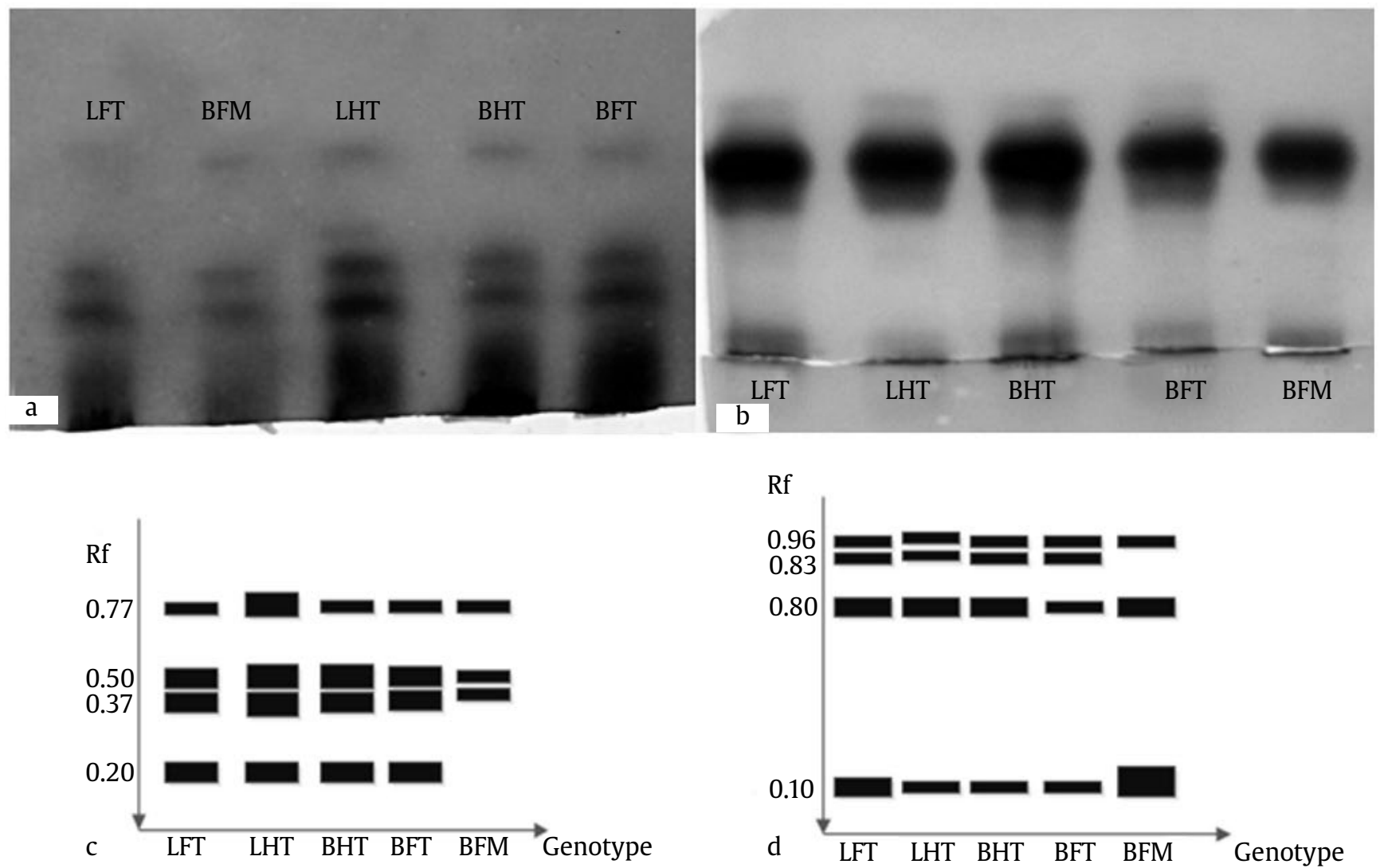

Figure 2. Electrophoregram of Esterase ( $a$ and $c$ ) and Peroxidase ( $b$ and $d$ ) enzymes. Electrophoregram of gel electrophoresis ( $a$ and b), schematic of electrophoregram ( $c$ and d). BFT: seedling from female flower of androgynomonoecious Banten accession, BHT: seedling from hermaphrodite flower of androgynomonoecious Banten accession, LHT: seedling from hermaphrodite flower of androgynomonoecious Lampung accession, LFT: seedling from female flower of androgynomonoecious Lampung accession, BFM: seedling from female flower of monoecious Banten accession 
Table 2. Plant, inflorescence sex types, flowers gender, and percentage of flower inflorescence type on the plant produced by genotypes of $J$. curcas

\begin{tabular}{|c|c|c|c|}
\hline Genotypes & Plant sex type & $\begin{array}{l}\text { Flower gender and flower } \\
\text { inflorescence type }\end{array}$ & $\begin{array}{c}\text { Percentage of flower inflorescence } \\
\text { type on the plant (\%) }\end{array}$ \\
\hline \multirow[t]{3}{*}{ BFT } & \multirow[t]{3}{*}{ Androgynomonoecious } & $\begin{array}{c}\text { Hermaphrodite, female, Male } \\
\text { (Androgynomonoecious) }\end{array}$ & 33.33 \\
\hline & & $\begin{array}{l}\text { Hermaphrodite, Male } \\
\text { (Andromonoecious) }\end{array}$ & 4.17 \\
\hline & & $\begin{array}{l}\text { Female, Male (Monoecious) } \\
\text { Male }\end{array}$ & $\begin{array}{r}60.41 \\
2.08\end{array}$ \\
\hline \multirow[t]{4}{*}{ BHT } & \multirow[t]{4}{*}{ Androgynomonoecious } & $\begin{array}{c}\text { Hermaphrodite, Female, Male } \\
\text { (Androgynomonoecious) }\end{array}$ & 12.50 \\
\hline & & $\begin{array}{l}\text { Hermaphrodite, Male } \\
\text { (Andromonoecious) }\end{array}$ & 85.00 \\
\hline & & Female, Male (Monoecious) & 0.00 \\
\hline & & Male & 2.50 \\
\hline \multirow[t]{3}{*}{ LHT } & \multirow[t]{3}{*}{ Androgynomonoecious } & $\begin{array}{c}\text { Hermaphrodite, Female, Male } \\
\text { (Androgynomonoecious) }\end{array}$ & 21.74 \\
\hline & & $\begin{array}{l}\text { Hermaphrodite, Male } \\
\text { (Andromonoecious) }\end{array}$ & 52.17 \\
\hline & & Female, Male (Monoecious) & $\begin{array}{r}17.39 \\
870\end{array}$ \\
\hline \multirow{5}{*}{ LFT } & \multirow{5}{*}{ Androgynomonoecious } & & \\
\hline & & $\begin{array}{c}\text { Hermaphrodite, Female, Male } \\
\text { (Androgynomonoecious) }\end{array}$ & 21.05 \\
\hline & & $\begin{array}{l}\text { Hermaphrodite, Male } \\
\quad \text { (Andromonoecious) }\end{array}$ & 5.26 \\
\hline & & Female, Male (Monoecious) & 28.95 \\
\hline & & Male & 44.74 \\
\hline BFM & Monoecius & $\begin{array}{l}\text { Female, Male (Monoecious) } \\
\text { Male }\end{array}$ & $\begin{array}{l}85.71 \\
14.29\end{array}$ \\
\hline
\end{tabular}

that are, androgynomonoecious (female, male, and hermaphrodite flowers), andromonoecious (male and hermaphrodite flowers) and male flowers. The BFT genotype has the highest percentage of androgynomonoecious and monoecious flower inflorescence.

Seedlings derived from the female flowers of Banten accession monoecious $J$. curcas produced two flower inflorescence types that were monoecious inflorescence (male and female flowers on the same inflorescence) and androecious (male flowers). The seedlings of female flowers from androgynomonoecious $J$. curcas produced monoecious inflorescence flowers, while the seedlings of hermaphrodite flowers produced higher andromonoecious inflorescence (male and hermaphrodite flowers in the same inflorescence) than other those flower inflorescence types. The seedlings of female flower from monoecious J. curcas produced of monoecious inflorescence flowers (Table 2).

Plants from seed originating from the female flowers on androgynomonoecius $J$. curcas produced offsprings with monoecious inflorescence flowers (male and female flowers on the same inflorescence) higher than other flower inflorescences. Plants from seed originating from hermaphrodite flowers on androgynomonoecius J. curcas produced andromonoecious flower inflorescence (hermaphrodite and male flowers on the same inflorescence) higher than other flower inflorescences. Plants from seed originating from hermaphrodite flowers on J. curcas Banten accessions were not generated inflorescence which has male and female flowers (Table 2). 


\section{Discussion}

The chromosomes number of $J$. curcas genotypes in this study were $2 \mathrm{n}=22$ chromosomes. This chromosomes number similar to the study conducted by Carvalho et al. (2008) and Sasikala and Paramathma (2010). The chromosomes length of $J$. curcas in this data was in line with the study of Reddy et al. (2013) which stated that the length of chromosome of $J$. curcas between 1 to $3.67 \mu \mathrm{m}$. The average length of the androgynomonoecious plant's chromosome was longer than the average for monoecious plants. The length of chromosomes can differ in different species in the same family, eventhough the numbers of the chromosomes are the same. The difference length between the androgynomonoecious plant's chromosome and the monoecious plant's indicated that there was a difference in the nitrogenous bases number (Harrison and Schwarzacher 2011). On the other hand, Moliterni et al. (2004) stated that chromosomes in plants with hermaphrodite flowers tend to have large variability, making a large difference in chromosomes size among genotypes possible. As in this study, that the androgynomonoecious plants have hermaphrodite flowers, whereas in the monoecious plants have no hermaphrodite flowers.

The variation of band pattern in PER and EST isozyme tends to be classified as qualitative variation, i.e. the presence or the absence of a band in the gel. These isozymes in this study as genetic markers for identifying the androgynomonoecious $J$. curcas genotype. The Peroxidase enzyme also has been used as a marker in the Hippophae rhamniodes female reproductive organs by Sharma et al. (2010). Band patterns of androgynomonoecious and monoecious plants which produced different variation showed there was a genetic difference between androgynomonoecious and monoecious. This difference was due to more than one gene in each of those plants which control each isozyme (Dewatisari et al. 2008).

The Rf value band pattern based on the result of Esterase and Peroxidase isozymes on J. curcas can be described as the pattern of alleles between genotypes of $J$. curcas were observed. The EST and PER enzymes from the five $J$. curcas genotypes were differentiated into two band patterns with three to four alleles. The BFT, BHT, LHT, and LFT genotypes which were androgynomonoecious plants had four alleles. Only the BFM genotype was a monoecious plant with three alleles (Figure 2). The difference between monoecious and androgynomonoecious $J$. curcas can also be seen from the types of flower gender owned by each inflorescence and sex type of plant.

Flower inflorescences produced from the androgynomonoecious plants (BFT, BHT, LHT, and LFT) did not have a consistent percentage of flower inflorescence type. Based on the flower gender and sex types of plants produced by each genotype showed that the androgynomonoecious J. curcas consistently has the male, female, and hermaphrodite flowers in the same flower inflorescence. Monoecious J. curcas consistently produced plant which has flower gender only male and female flowers in the same flower inflorescence. Adriano-Anaya et al. (2016) found female, male, and hermaphrodite flowers in the study accessions and based on the proportion of each flower gender, plants were classified as gynoecious, androecious, andromonoecious, androgynomonoecious. Based on evolution of sexuality, androgynomonoecious and andromonoecious J. curcas are the intermediate state, whereas monoecious $J$. curcas is modern state (Charlesworth 2016). J. curcas sex types in this study similar with studied by Dasumiati et al. (2017) that androgynomonoecious and monoecious of $J$. curcas have stable sex type after stem cuttings propagation. The expression of flower gender is controlled by of genetic (Susila et al. 2010) and controlled by a pair of sex chromosomes, like in papaya (Ming et al. 2007).

The females and hermaphrodites flowers have different resource allocation pattern. This pattern suggests that female flowers may allocate resources to increase their fitness in a less favorable environment more than those hermaphrodite flowers (Delph and Carrol 2001). The hermaphrodites flowers would be stronger facilitators than females because they incur a greater allocational cost of producing pollen (Cranston et al. 2012). Another factor that intervenes in sex modification is photoperiod, which has masculinizing or feminizing effects, depending on day duration. The short days decreased temperature to female sex phenotypisation and increase the amount of flower hermaphrodite flowers. This fact is realizable by the regulation of endogenous hormones level (Trutã et al. 2007). 
In this study, we provided valuable information based on isozyme characters, and chromosomes showed the relationship between the size of the chromosome, the number of alleles, with flower gender in inflorescences type. The genotypes of androgynomonoecius $J$. curcas has four alleles, whereas genotypes offsprings derived from the seeds of hermaphrodite flowers have a size longer than the chromosome derived from the seeds of the female flower. Therefore, isozymes (Peroxidase and Esterase) and chromosome size could be used as markers to differentiate between androgynomonoecious and monoecious plants $J$. curcas. Both androgynomonoecious and monoecious $J$. curcas plants have diploid chromosomes $(2 \mathrm{n}=$ 22), but chromosomes from androgynomonoecious plants from hermaphrodite flowers have a longer than that of monoecious plants. Characteristics of the androgynomonoecious plants in this study were almost the same as with their mother plant. The flower inflorescence type derived from androgynomonoecious plants were unstable, due to androgynomonoecious is intermediate state (Charlesworth 2016). This information is essential for the establishment of controlled crossing program and relevant for the development of a clone-based breeding program.

\section{Acknowledgements}

We greatly thanks to the Research Center for Biological Resources and Biotechnology (PPSHB), and The Indonesian Institute of Sciences Cibinong for the laboratory facilities.

\section{References}

Andriano-Anaya ML et al. 2016. Sex expression and floral diversity in Jatropha curcas: a population study in its center of origin. Peer J:1-18.

Asante IK, Laing EI. 2001. Isozyme variation and genetic diversity at 3 phosphoglucose-isomerase(PGI) [glucose1-phospate] gene loci in nine cowpea accessions (Vigna unguiculata (L.) Walp) from three agroecological zones. West African Journal of Applied Ecology 2:1-8.

Carvalho CR et al. 2008. Genome size, base composition and karyotype of Jatropha curcas L., an important biofuel plant. Plant Science 174:613-617.

Charlesworth D. 2016. Plant sex chromosomes. Annual Review of Plant Biology 67:397- 420.
Cranston BH et al. 2012. Gender and abiotic stress affect community-scale intensity of facilitation and its cost. Journal of Ecology 100:915-922.

Dasumiati et al. 2015. Flower characteristics and phenology of and romonoecious Jatropha curcas. Pakistan Journal Botany 47:1501-1510.

Dasumiati et al. 2017. Sex type in flowering of Jatropha curcas. Biodiversitas 8:442-446.

Dellaporta SL, Urrea AC. 1993. Sex determination in flowering plants. The Plant Cell 5:1241-1251.

Delph L, Carrol S. 2001. Factors affecting relative seed fitness and female frequency in a gynodioecious species, Silene acaulis. Evolutionary Ecology Research 3:487-504.

Dewatisari WF et al. 2008. Keanekaragaman beberapa varietas Sansevieria trifasciata berdasarkan karakter anatomi, isozim, dan kandungan saponin. Bioteknologi 5:56-62.

Escudero M et al. 2010. Karyotype stability and predictors of chromosome number variation in sedges: a study in Carex section Spirostachyae (Cyperaceae). Molecular Phylogenetics and Evolution 57:353-363.

Hartati S. 2009. Jarak pagar hermaprodit, interaksi faktor genetik dan lingkungan. Info Tek Perkebunan 1:2.

Hartati SR et al. 2009. Keragaan morfologi dan hasil 60 individu jarak pagar (Jatropha curcas L.) terpilih di kebun percobaan Pakuwon Sukabumi. Jurnal Littri 16:152-161.

Harrison HJS, Schwarzacher T. 2011. Organisation of the plant genome in chromosomes. The Plant Journal 66:18-33.

Makkar H et al. 2008. Variations in seed number per fruit, seed physical parameters and contents of oil, protein and phorbol ester in toxic and non-toxic genotypes of Jatropha curcas. Journal of Plant Science. 3:260-265.

Ming R et al. 2007. Sex determination in papaya. Seminars in Cell and Developmental Biology 18:401-408.

Moliterni CVM et al. 2004. The sexual differentiation of Cannabis sativa L.: a morphological and molecular study. Euphytica 140:95-106.

Plummer JA et al. 2003. New methods for comparison of chromosomes within and between species. Caryologia 561:227-231.

Raju AJS, Ezradanam V. 2002. Pollination ecology and fruiting behaviour in a monoecious species, Jatropha curcas L. (Euphorbiaceae). Current Science 83:1395-1398.

Reddy MP et al. 2013. Karyology and genomics of Jatropha: current status and future prospect. Genetic Improvement and Biotechnology 2:301-320.

Sasikala R, Paramathma M. 2010. Chromosome studies in the genus Jatropha L. Electronic Journal of Plant Breeding 1:637-642.

Sharma A et al. 2010. Molecular identification of sex in Hippophae rhamnoides L. using isozyme and RAPD markes. Forestry Studies in China 12:62-66.

Shirkot P et al. 2009. Identification of gender Hippophae salicifoia using isozymes as sex markers. Indian Journal of Forestry 32:231-237. 
Stalker HT, Mozingo LG. 2001. Molecular markers of Arachis and marker-assisted selection. Peanut Sciences 28:117-123.

Susila T et al. 2010. Effect of plant growth regulators on flowering and yield of watermelon (Citrullus lanatus (Thunb.) Matsumara and Nakai).Journal of Horticultural Science and Ornamental Plants 2:19-23.

Talukdar D. 2010. Flourescent-banded karyotype analysis and identification of chromosomes in three improved Indian varieties of grass pea (Lathyrus sativus L.). Chromosomes Science 13:3-10.
Trutã E et al. 2007. Some aspects of sex determinism in hemp. Analele Ştiinţifice ale Universităţii "Alexandru Ioan Cuza", Secţiunea Genetică şi Biologie Moleculară, TOM VIII: 31-39.

Yunus A. 2007. Identifikasi keragaman genetik jarak pagar (Jatropha curcas L.) di Jawa Tengah berdasarkan penanda isoenzim. Biodiversitas 8:249-252. 